\title{
Innovation and entrepreneurship in Catalan private laboratories: origins and rise of Grifols Lab (1880-1955)
}

\begin{abstract}
Studying the evolution of private medical clinics is extremely useful in understanding the history of the Catalan healthcare system where, from the 19th century onwards, a Marshallian atmosphere of flows of knowledge, people and technology has resulted in close connections between the public and private practice of modern medicine. The history of the Grifols Laboratories, from 1880 to the 1950 s, is a relevant case study in this context, as it highlights patterns that were repeated in other medical laboratories in Catalonia a century ago. But Grifols is also particularly interesting both because of its survival and evolution to this day, and for its curation of its own historical archive.

This article aims to understand how a small laboratory in the healthcare district of Barcelona built its scientific foundations on laboratory medicine during the early 20th century, and finally changed its business strategy because of the Spanish Civil War, becoming a family pharmaceutical company. The sources are documents from the Grifols archive and interviews with managers at the company. The findings highlight the importance of interdisciplinary analysis, suggesting that both scientific and business adaptations by successive generations are equally important in explaining the success of Grifols Laboratories. Science-based family firms that endure over time not only acquire specialised knowledge to compete in the market, but also knowledge about transferring entrepreneurship in the long term. In Grifols case, knowledge from younger generations was crucial to adapting their activity, first to a changing scientific paradigm and then to a precarious national market.
\end{abstract}

Keywords: Innovation; Entrepreneurship; Pharmaceutical Laboratories; Healthcare; Catalonia; Grifols

Corresponding author: e-mail: cristina.sans.ponseti@uab.cat

Received 17 September 2020 - Accepted 15 October 2020

This is an Open Access article distributed under the terms of the Creative Commons Attribution-Non-Commercial-No Derivatives License (http://creativecommons.org/licenses/by-nc-nd/4.0/), which permits non-comercial re-use and distribution, provided the original work is properly cited, and is not altered or transformed in any way. 


\section{Introduction}

Studying the evolution of private medical clinics is extremely useful in understanding the history of the Catalan healthcare system where, from the 19th century onwards, a Marshallian atmosphere of flows of knowledge, people and technology has resulted in close connections between the public and private practice of modern medicine. In this regard, a complete understanding about the modernisation of the Catalan healthcare cluster has to consider both hospitals and private clinics. The history of the Grifols Laboratories, from 1880 to the 1950s, is a useful case study in this context, as it highlights patterns that were repeated in other laboratories and institutes of medicine in Catalonia a century ago. But it is also particularly interesting both because of its survival and evolution to this day, and for its curation and conservation of its own very complete historical archive.

Grifols' scientific history dates back to the 1880 s, and it could be said that during its more than 140 years of history, three ideas are key to explain its scientific foundations: its understanding of the laboratory as a diagnostic and a therapeutic tool; its own technological developments, closely linked to needs that arose from the laboratory; and the strong influence the Barcelona medical cluster and influences from abroad had on it. It is precisely the continuous updating of these three elements, in addition to changing business strategies, that led to the survival of this science-based family firm over such a long period of time and through various rapidly changing social and political circumstances.

This article will endeavour to analyse which modernisation strategies, both scientific and business-related, were used in the case of Grifols between 1880 and 1955. The first part will analyse how the family's medical practices originated before Grifols became a public limited 
company in 1940. We find that the first 30 years of activity, between 1880 and 1909, culminated in the adaptation of the homeopathic tradition to a new medical approach, and left behind a very specific understanding of the laboratory: a bacteriological-therapeutic laboratory. Between 1909 and 1923, both the potential of this duality and the search for technological innovation were exploited by the family, in a context of profound change in medical practices and the emergence of medical disciplines such as haematology. Later, until the beginning of the Spanish Civil War, we see how the techno-scientific advances that led to haemotherapy were received and adapted rapidly by those professionals who already dominated the scientific manipulation of blood.

In the second part, the minutes of the Grifols Laboratories shareholders meetings will be used to study how the company's strategy changed after the civil war, and to what extent the then current political situation was significant in this decision. We identify two major stages from the point of view of scientific specialisation: the first five years, between 1940 and 1945, when it was a small family business organised around the sale and production of pharmaceutical and nutritional products; and the subsequent years, when the business diversified and haemotherapy took on a more important role, but which also required Grifols to attract shareholders from outside the family in order to obtain the investment they needed to grow the company.

\section{The beginnings (1880-1910s): a private homeopathic laboratory}

The first member of the Grifols family with medical training was Josep Antoni Grifols Morera (1857-1931). Born in Vilanova i la Geltrú, Grifols Morera graduated from the Faculty of Medicine of the University of Barcelona in 1880, and during the final years of his degree he 
established relationships with homeopathic specialists, which sparked his strong interest in the discipline (Puig Rovira 2003, 157).

In the 1880s the influence of homeopathy grew increasingly in Spain, although its professional community was disunited. In Barcelona, by the end of the decade, there were 14 homeopathic doctors, who operated with no coordination between them at all (Puig Rovira 2003, 158). However, aware that the institutionalisation of the discipline would give them legitimacy on both a scientific and social level, they founded the Homeopathic Medical Academy of Barcelona ("Academia Médico Homeopática de Barcelona", the AMHB) on 13 April 1890 (Piqué 2018). Among the founding partners was Grifols Morera, who in 1887 moved permanently to Barcelona, opening what would become his first medical practice in the capital (Josep Antoni Grifols Morera’s Obituary in La Vanguardia, June 12, 1931).

Grifols Morera's practice was a private dispensary located in the Raval neighbourhood in the old centre of Barcelona, where it carried out therapeutic experimentation in line with the doctrinal foundations of homeopathy. Certainly, both the location and the business format he employed both became quite common among Barcelona's medical class in the mid- to late 19th century. Works such as Zarzoso and Martínez-Vidal (2016) and the one of Zarzoso published in this issue explain how the Raval district, which by the 1920s had become a marginalised area known locally as the "Barrio Chino", had previously had an important role in transforming the medical practice. With its high concentration of factories, people and health services (the Hospital de la Santa Creu and the Faculty of Medicine the most important among them), 'the old city' area of Raval acted as a medical hub and saw the establishment of the new private dispensaries and the first surgical clinics in the city. In the case of homeopathy, moreover, the presence of the main homeopathic pharmacy in the neighbourhood, the Farmacia Grau-Alta, 
further favoured the presence of these new dispensaries. And in the same way, Piqué (2018) explains how homeopathy, today on the whole discredited by orthodox medicine, was at that time within the official medical body. Together with the creation of the AMHB and the foundation of the Hospital Homeópata del Niño Dios (1902), clinics such as Grifols Morera's were fundamental pillars for the great expansion that the discipline experienced in the city during the first decades of the 20th century, and which culminated in the great popularisation of homeopathic remedies between 1902 and 1910 among very diverse social sectors (Piqué 2019, 1338-1342).

The practice of Grifols Morera, therefore, located in the heart of Barcelona's medical community and within the context of the rising popularity of homeopathy, gained popularity and developed a large clientele. In addition, as a result of its own expansion plans and the tendency of new homeopathic practices to move outside what had been the city walls, it moved in 1891 to a larger practice located in Portaferrissa Street (Puig Rovira 2003, 158).

However, the professionalisation and popularisation of the discipline was also marked by fierce doctrinal debates at a time of great upheaval in the medical conceptual framework. During the last decade of the 19th century and the first decades of the 20th, Western science experienced a period of consolidation of a new medical model: the acceptance of the bacterial theory opened the way to the development of positivist medicine, and led to a new understanding of life and disease with a growing interest in reducing all vital phenomena to physicochemical phenomena. This led to the progressive introduction of laboratory medicine, where the laboratory and its 
practices took on a central role and become the key source of scientific knowledge (Piqué 2018, 202). ${ }^{1}$

The positivisation of physiology had an unequal reception in vitalist sectors, which entered into constant redefinitions of their foundations. Piqué (2018) published what is considered a reference work in terms of understanding how the important Catalan homeopathic school had to engage in various strategies of scientific and social legitimisation, in order to establish the validity of its therapeutic system and so avoid falling into the scenario of being excluded from the orthodox medical body. One of these strategies was the approach they took towards laboratory methods, which created strong epistemological differences within the collective. Some argued that making adaptations to accommodate reductionism was in direct conflict with the ontological conception of the discipline of homeopathy. Other parties, however, tried to submit their research on homeopathic remedies to the methods and technologies of the laboratory, i.e. they tried to explain the therapeutic action of homeopathic remedies through physiological experimentation. The multiplicity of interpretations led to a division within the AMHB and in March 1904, those who supported the idea of doctrinal renovation, Grifols Morera among them, ended up founding their own institution, the Homeopathic Institute of Barcelona ("Institut Homeòpata de Barcelona", the IHB). Grifols Morera first became the Vice President of IHB and then President of its Scientific section (Diario de Villanueva y Geltrú, January 19, 1906, and January 24, 1907).

The IHB was founded with the purpose of taking forward the adaptation of the homeopathic tradition to the new scientific paradigm, and the laboratory was a key element since it was used

\footnotetext{
${ }^{1}$ For nuanced views of the category 'Laboratory medicine' see: Cunningham and Perry (1992) and Brunton (2004).
} 
as "an instrument of legitimisation taking advantage of its undefined nature" (Piqué 2018, 212). As such, homeopathic doctors took advantage of its methods and technologies to back up and support homeopathic therapies with arguments from the new science, while also taking advantage of the diagnostic tools that the laboratory offered. By investigating the subject of study, that is, the patient, they argued that they would not fall into the "empty" empiricism which characterised the new model and which was in opposition to the doctrinal bases of homeopathy, which strongly defended the holistic study of the individual (Grifols Morera 1904).

In March 1907, Grifols Morera moved his practice to a larger premise in Plaza Urquinaona (Diario de Villanueva y Geltrú, March 17, 1907). Only two years later, both the practice and its patient portfolio were handed over to his son, and the practice was renamed as the Central Institute of Clinical, Bacteriological and Chemical Analysis ("Instituto Central de Análisis Clínicos, Bacteriológicos y Químicos”, henceforth, the Institute).

\section{The Central Institute for Clinical, Bacteriological and Chemical Analysis (1909-1923): the emergence of haematology, without haematologists}

During the first decade of the 20th century, a new class of young doctors, interested in both homeopathy and new scientific discoveries, approached and joined the IHB (Piqué 2018, 196). Among them were Josep Antoni Grifols Roig (1985-1976), son of Grifols Morera, and his classmate Ricard Moragas Gracia (1883-1966), both of whom had graduated in medicine from the University of Barcelona in 1909. Together with a third fellow student, Dr. Lluís Celis Pujol (1887-1941), they were the driving force behind converting Grifols Morera's clinic into the Institute but still following the medical practices started by him. 
Although the Institute was founded in 1909, because Grifols Roig left for the winter semester at the University of Munich in October of that year (Ludwig-Maximilians-Universität München $1909,78)$, it did not begin its activities until a year later. Economically supported by his family, Grifols Roig's stay in Munich was very important for his technical training as he began to specialise in clinical analysis, pathological anatomy and state-of-the-art laboratory technologies. He trained in histology under Dr. Siegfried Mollier (1866-1954) and in bacteriology under Max von Gruber (1853-1927). With the latter, who was also Karl Landsteiner's teacher, he learned the technique and science of agglutination, and the traditional method of Wassermann's reaction to detect syphilis which had only been developed three years earlier. Wassermann's reaction was a crucial technique for the Institute, as it would be the main source of income for the laboratory for many years (Fernández Pérez and Sabaté 2017). Indeed, over the years, Grifols Roig built on and perfected the technique to the extent that he finally proposed a new method to avoid false positives, which he would end up presenting in 1913 as a doctoral thesis in order to obtain the degree of Doctor of Medicine and Surgery at the Faculty of Medicine of the University of Barcelona, and which he patented in 1917 (Grifols Roig 1913 and 1917).

The technical profile that Grifols Roig's classmate and business partner Moragas acquired was quite similar. From 1906 to 1909, he was an intern at the Bacteriology and Serology Laboratory of the Hospital de Sant Pau, where he also learned the technique of agglutinating reactions as a means of diagnosing infectious diseases. He then worked as an assistant in the Laboratory of Bacteriology and Chemical Analysis at the Hospital de Niños Pobres in Barcelona, combining it with his work as director of the Laboratory of the Academy of Medical Sciences ("Acadèmia i Laboratori de Ciències Mèdiques”, the ALCM) from 1908 to 1912 (Hospital de la Santa Creu 
i Sant Pau 1948). Celis, on the other hand, approached the laboratory from a more academic perspective and took a special interest in teaching: in 1911, he was in charge of teaching histology and pathological histology at the ALCM, and in 1914, he gained a position as assistant professor in the Faculty of Medicine at the University of Barcelona, where he also taught pathological anatomy and general pathology (Zarzoso 2020).

Alongside these activities, the three doctors ran the Institute from 1910 to 1923 . The Institute was a private "biological research laboratory", where a series of clinical, histopathological and cytological analyses were carried out using the latest laboratory techniques developed in bacteriology and chemistry (Celis, Grifols i Moragas ca. 1915). They used various human fluids as samples (blood, sputum, faeces, urine or exudates) but blood was undoubtedly the most frequent. Using the technique of agglutination, they performed serodiagnoses to determine the presence of different infectious diseases in the individual, such as typhoid fever, paratyphoid A and B, and Mediterranean fever. Serological tests such as quantitative Wassermann's reactions to diagnose syphilis and Abderhalden's reactions to determine pregnancies were also carried out. However, what made the Institute particularly interesting was that, in addition to the diagnostic aspect typical of the bacteriological laboratory, a second fundamental pillar was added: therapeutic investigation. Using the knowledge they had developed in serology, Moragas and Grifols began to produce preventive vaccines against typhoid fever, cholera and anthrax; as well as auto-vaccines - serums prepared by diluting or inactivating germs found in the patient's own blood - for acne, furunculosis and urethritis. These preventive vaccines and auto-vaccines, once ingested or injected, helped the patient to develop or strengthen their own immunity against the pathogen involved (Celis, Grifols i Moragas ca. 1915). The Institute's 
clients were individuals or other physicians who contracted its services to conduct bacteriological analyses of samples that they sent to the Institute, or to purchase vaccines.

The first years of the Institute have to be understood as it being a dual function laboratory: the bacteriological laboratory capable of diagnosing diseases and the dispensary capable of creating therapeutic remedies. That is to say, the Institute continued the homeopathic tradition of Grifols Morera, but its three founding partners also brought to the practice the new medical paradigm of bacteriology, enabling them to now not only make remedies, but also to diagnose in their own laboratories. It is no coincidence that serotherapy and vaccinotherapy were disciplines which for years offered discourses in favour of homeopathy (Moragas 1915, 89). This trend was reinforced by the emergence of a new pharmacological model during the first decades of the 20th century which revolutionised the field of medicine (Piqué 2019). The medicines that were marketed at the Institute had their own idiosyncrasies in that the auto-vaccines were personalised remedies.

This hybrid nature of the diagnostic and therapeutic aspects was not exclusive to the Institute, but it is a very useful characteristic to use to describe how a medical tradition could be reinterpreted by young physicians trained and interested in the methods of a new medical paradigm. What is more, it is fundamental to the complete understanding of the subsequent activity of the Grifols family, since the approach was transferred to its successor, Grifols Laboratories ("Laboratorios Grifols SA", LG). With the advent of the technical and scientific developments which made blood transfusions possible, therapeutics became more widely available, but clinical analysis continued to be the mainstay of the business, not only for the Institute but also for LG, until well into the 1950s. This central role given to the laboratory was linked to two aspects that were equally important in the establishment of the company that was 
to come later: in-house technological developments arising from the needs of the laboratory and the response to strong local and outside influences.

As regards the former, doctors developed a multitude of technological developments to solve problems they encountered in the laboratory on a daily basis. Based on the skills obtained in the creation of the first serums and reagents for carrying out biological analyses (which included physiological solutions using distilled water, solutions of washed red blood cells and serums extracted from animals), early in the 1920s, Grifols Roig was able to develop the first control serums for blood transfusions on the market in Barcelona, which were essential for safe transfusions following the creation of the Hemobanco (Blood and Plasma Bank) in 1945 (Laboratorios Grifols 1944). The outbreaks of endemic typhoid in Barcelona early in the century were also a driving force, prompting Moragas and Grifols to develop rapid fermentation tubes to detect bacillus coli in public fountains in Barcelona in 1916 (Moragas and Grifols 1916). Nevertheless, the main problem that doctors had to face during their daily laboratory practice, both to carry out analyses and to create vaccines, was maintaining asepsis. Most of the patented technical materialisations were devices that sought to safely maintain the sterility of the fluids they contained:

"The practice of haemoculture is nowadays a frequent and necessary operation, especially to be able to discover which is the causal agent of numerous infections, which clinically are revealed by the septicemic picture, and at the same time to be able to prepare, if necessary, an auto-vaccine, in order to make the treatment as specific as possible for the disease. However, the great problem of blood cultures today is the lack of sterility. When the blood is put in the solution, germs that do not come from the blood can be introduced". (Moragas and Grifols 1914, 77). 
In 1914, Moragas and Grifols developed the first instrument capable of taking blood directly from the vein and seeding it onto a medium: a sterilised vacuum flask connected to a needle through which the blood was extracted. Based on this device, which Grifols called the flébula aspiradora, he developed and patented eight different instruments between 1916 and 1929 (Grifols Roig 1916 and Grifols Roig 1929a). As with clinical analyses, technological innovation was also particularly important for the Catalan medical market: the aim was for any doctor to be able to carry out a blood test easily and, if they did not have a good laboratory, to be able to send the sample to a specialised laboratory such as the Institute with the assurance that it would arrive completely isolated from external pathogens (Grifols Roig 1928a). To this end, he not only offered his services as an analyst, but also built the business around the apparatus he developed.

The third and final key factor in understanding the legacy which the Institute left to LG is its investment in building an important network of national and international connections. Works such as those of García-Canal et al. (2018) and Fernández-Pérez et al. (2019) have shown that early contact with advanced international markets was one of the keys to the subsequent successful internationalisation of the laboratories. This contact was, in the case of the Institute, preceded by strong scientific influences from abroad. Grifols Roig's stay in Munich to study his specialism was followed by other international collaborations: the presence at the Institute in 1916 of Dr. Paul Gordan (1869-1923), the Director of the bacteriology laboratory in Danzig between 1907 and 1911 (Sancho Gallel in El Día, November 23, 1918); and the Institute's collaboration with Dr. Helmolz in 1924 to develop a new analytical method to determine the amount of urea in blood (Grifols and Helmholz 1924). 
However, this first stage of the Institute demonstrates in practical terms what the birth of modern haematology meant, and the professional hybridisation which occurred to give rise to the profession of haematologist. Despite developing the techniques that were laying the foundations of the discipline, the protagonists of this work did not call themselves haematologists since neither the discipline was as yet not institutionalised and nor had they developed a professional identity. Nevertheless, strongly practical interests guided their research on blood (whether in the field of diagnosis or therapy), creating new foundational knowledge through their dual laboratory. Grifols, Moragas and Celis, all doctors who sought to modernise their profession, came from a scientific culture which was witnessing the emergence of new medical specialities, the consolidation in Barcelona of a very specific form of urban medicine, and the introduction and assimilation of new diagnostic methods from abroad. All this made for a professional hybridisation that advanced their practices, accompanied by their own technological innovations in overcoming the difficulties that had arisen in their laboratories. The article of Zarzoso, in this same special issue, shows in a broader sense how this process of medical specialisation was configured in the city of Barcelona, and the fundamental importance of laboratory medicine in this process.

\section{The professionalisation of the Institute's activity and the arrival of haemotherapy (1923-} 1939)

In 1923, the Institute moved to the Eixample district in Barcelona, and Grifols Roig himself took over its management (Grifols Group 2001). Celis was appointed Professor of Histology and Pathological Anatomy at the University of Barcelona in the same year, but continued to collaborate with the Institute on an ad hoc basis. Moragas and Grifols became increasingly separated from the homeopathic institutions of which they had been a part (Piqué 2018). 
Moragas worked in the Laboratory of the Hospital de la Santa Creu, where in 1930 he was appointed Director, and two years later, he founded the hospital's first Blood Transfusion Service, together with Dr. Manuel Miserachs (Hospital de la Santa Creu 1948). The role of Moragas and Miserachs, and thus of the hospital's laboratories, was very important in the transformation of hospital practices at the Hospital de la Santa Creu i Sant Pau.

Just as the Raval district was an important element in the transformation of Barcelona's medical class at the end of the century, the relocation of medical clinics to the bourgeois Eixample district during the first third of the 20th century was also decisive. The new precepts of laboratory medicine not only exerted their influence at the epistemological level of medicine, but also changed healthcare systems at other levels. In Barcelona, a new model of private surgical clinics was starting to be set up in this neighbourhood, with open spaces and welldefined and separate areas, in accordance with aseptic and antiseptic new ideas (Zarzoso and Martínez-Vidal 2016). As a result, auxiliary services like the Institute followed the trend, firstly by seeking out a bourgeois clientele, and then also promoting medical practice as a product for consumption among large sections of the urban population, giving an alternative model to the charitable public hospitals aimed at the poor, as Zarzoso shows in this issue.

This early activity of the Grifols family cannot be understood without this urban context: the trends of the Barcelona healthcare district played a fundamental role in the establishment of the private medical care model and Grifols Roig knew how to adapt the Institute to consolidated his activity. From his new practice located on Rambla Catalunya, this second stage of the Institute (1923-1939) was one of the professionalisation of the scientific activity, but always building on the foundations that had been established in previous years. Furthermore, in this second period a new line of therapeutics was launched: the introduction and assimilation of the 
techno-scientific resources needed to make blood transfusions more effective opened up access to the technique. The discovery of the existence of the different blood groups by Karl Landsteiner in 1901, the development of new techniques and apparatus for the safe extraction and injection of blood during the first decades of the 20th century, and the establishment of sodium citrate as an anticoagulant substance by Luis Agote in 1914, established the technoscientific basis that led to the World War I becoming a field of experimentation for the use of transfusions on a large scale (Starr 1998). All of these innovations became popular among the medical class during the 1920s, meaning the practice of blood transfusions changed from being a purely military practice to one used regularly in civilian medicine and resulted in improved safety and standardised practices (Schneider 2003). A new discipline was emerging: haemotherapy, or the study of the therapeutic value of blood.

The arrival of the recent innovations was quickly taken advantage of by those professionals, like Grifols Roig and Moragas, who already had great skill in the use of blood in the laboratory. It is not surprising, then, that in 1925 the first indirect blood transfusions were registered at the Institute, possibly being some of the first in Catalonia (Laboratorios Grifols 1951). This led to the creation of a second centre that same year: the Institute of Biological Therapeutics ("Instituto de Terapéutica Biológica", the ITB) (1925-1939), also under the direction of Grifols Roig (Faura Bordas 1940).

The instruments used for transfusions at the two practices were manufactured in-house, based on models used in Europe. On May 23, 1928, Grifols Roig patented its first flébula transfusora, a transfusion device, similar to a Kimpton-Brown-Percy tube, but without the rubber tubes as an innovation implemented to reduce the possibility of contamination (Grifols Roig 1933a). Grifols Roig used the knowledge they had gained during years of developing the flébulas 
aspiradoras: once the technique for storing blood in sterile conditions had been achieved, he needed to find a way to store the extracted blood to prevent it from coagulating before it was transfused to the recipient. He did this first by means of paraffin, and then using sodium citrate, and managed to make transfusions using the flébula system, the first indirect transfusion system patented in Spain, at a time of great debate about the suitability of the technique as opposed to direct transfusion. Despite these reservations on the part of some practitioners, the equipment was also patented in Germany that same year, in France and Great Britain the following year, and in the USA in 1933 (Grifols Roig 1928b, 1929b, 1929c and 1933b).

However, its high cost meant that it was not a great commercial success, despite it being Grifols Roig's most important contribution to the emerging discipline. Thanks to the flébula, the Institute was able to organise a bank of Barcelona blood donors early in 1928, and thus provide its services to the three most important public hospitals in the city (La Vanguardia, August 5, 1928). Once again, the technological innovation of the Institute also led to the increased use of its other services.

The creation of a second Institute focused on therapeutics demonstrates how the dual functions of the laboratory were enhanced and professionalised during this middle period of the business. This base built on the Institute's own technological and technical development as well as the further development of their international network continued during the following decade. Thanks to the experience Grifols Roig had developed in the production of auto-vaccines, in 1931 the Sociedad General de Farmacia approached him with a view to jointly producing various biological products and pharmaceutical specialities (Grifols Roig 1933c). In collaboration with the Sociedad and under the name Laboratorios OM, Grifols Roig continued to produce vaccines and medicines based on isolating pathogens, such as the OM anti- 
colibacillary vaccine, the preventive typhoid vaccine and the Normaflora intestinal vaccine, and later, in 1944, they made the first attempt to produce penicillin in Spain under the name of Penicillin OM (La Vanguardia, March 12, 1944, and Grifols Lucas 1945). The vaccines, in oral format, were very successful and were commercialised in Switzerland and a number of South American countries (Grifols Group 2000). This was the first industrialisation of biological products for the family, an early stage in the development of LG. Nevertheless, although also of great importance for the business during the 30s were the dietary products developed at the Institute. At the same time, efforts were being made to keep the company well-connected internationally: in 1935, an association was established with the Lister Institute of Preventive Medicine in London, from which Grifols Roig developed a personal friendship with Dr. Robert Race, Director of the Medical Research Council Blood Group Unit (Laboratorios Grifols 1953).

The outbreak of the Spanish Civil War would, however, abruptly change the evolution of the Institute. The organisation and mobilisation of professionals on both sides of the conflict, and the new methods characteristic of war medicine, led many scientific centres to cease their activity and participate in new organisations that would also create new knowledge and ways of using blood (Palfreeman 2016; Zarzoso 2018, and Starr 1998). This was the case with Moragas and Miserachs, as well as two of Grifols Roig's sons, Josep Antoni Grifols Lucas (1917-1958) and Victor Grifols Lucas (1919-2015), all of whom joined the Blood Transfusion Service at the Front ("Servei de Transfusió de Sang al Front", the STSF) led by Frederic Duran i Jordà (1905-1957). The war, in addition to bringing about great changes in the use of blood, also led to a deep economic crisis that would affect all subsequent scientific activity, as well as the market. Private businesses had to adapt, as did scientists. From this perspective it is easy to understand why the Institutes became Laboratorios Grifols S.A. the following year. The need 
to protect a business which was fundamental for the family, in a fragile economic market and in changing social circumstances, was certainly the main trigger for change. To effect this protective strategy, all the recognition and scientific experience developed by the Grifols Roig over the previous 60 years was exploited, especially in terms of looking for new partners outside the family who could provide the necessary capital required by the new company. This was a business modernisation strategy, as or more important than that carried out within the family's scientific practices and was essential for the survival of the business.

\section{Business growth, productive diversification and introduction of outsider shareholders after the Civil War (1940 - 1965)}

Between 1940 and 1965 the ownership structure which had existed prior to 1940 at the Institute changed profoundly at Grifols Laboratories (LG), as did its corporate governance and the productive specialisation developed by Grifols Roig. ${ }^{2}$ After the Spanish Civil War, the industrial fabric of Barcelona - already a very important manufacturing centre before the war - grew rapidly. It seems that the autarky favoured industrial concentration, and import restrictions appeared to boost local production and foster the development of small and medium-sized industrial activities (Tatjer 2006). In the case of pharmaceutical industries, the high degree of specialisation of many doctors and chemists in Barcelona's healthcare district led to the emergence of a large conglomerate of industrial laboratories, including Laboratorios Ferrer SL (1940), Inibsa (Industrial Ibérica Químico-farmacéutica SA) (1948), Laboratorios Almirall SA (1943) owned by Antoni Gallardo, and Laboratorios Hubber (1952) by his brother Felix Gallardo (Morell 1996a and Morell 1996b). Others, like the Laboratorio Experimental de

\footnotetext{
${ }^{2}$ For a broad and general review of the history of Grifols Laboratories, see Avellà and Miquel (2015) and Grifols Lucas (2009).
} 
Terapéutica Inmunogama (known as Laboratorios Leti) which had been founded earlier, in 1919, inspired by the Municipal Laboratory of Barcelona led by Dr. Turró, intensified and industrialized their activity during this decade. Many of them, along with LG, joined forces in the form of a lobby known as the National Business Association of the Pharmaceutical Industry (1963), or Farmaindustria, during the 60s.

This demonstrates that it was not hard to find pharmaceutical industries with a scientific background similar to that of LG during these years, but bad business decisions resulted in many of them experiencing a drop-in activity or even disappearing in the following years. The case of Instituto Llorente is a good example of this scenario (Mateo de la Hoz 2016). The study of the business strategy followed by the Grifols family is therefore a point of special interest in understanding their later success.

Laboratorios Grifols SA was incorporated in Barcelona before the notary José Faura Bordas on 18 November 1940 (Arxiu Històric Grifols Barcelona. Deed of Incorporation of the Company entitled Laboratorios Grifols SA. November 18, 1940, from the Barcelona Protocols Archive, authentic copy drawn up by Mr. Cruz Usatorre y Gracia). The deed of incorporation states that a commercial company was set up by Grifols Roig, a physician by profession, and his wife Magdalena Lucas Viñas, both residents of Barcelona at 102 Rambla de Catalunya, and Aureliano Mas Ballarin, an accountant by profession and resident of Barcelona at 21 Balmes Street. The share capital was set at 500,000 pesetas distributed in 500 shares of 1,000 pesetas nominal value each to bearer, and 100 founder's shares which did not represent capital neither did the bearer have the right to benefit from the company's profits, although they did have the right to intervene in the administration of the company owned by Grifols Roig. With regard to 
ownership, the deed of incorporation of LG states that Grifols Roig purchased 170 shares representing a capital of 170,000 pesetas:

"Ten thousand of which he is obliged to pay in cash into the company's social fund for the whole day on the day of incorporation, while the remaining one hundred and sixty thousand are to be paid in kind through the signing over of the following to the same company named in this act: all the assets of the establishments which he founded under the names "Instituto Central de Análisis Clínicos" and "Instituto de Terapéutica Biológica" in 1909 and 1925 respectively and which will continue under the company "Laboratorios Grifols SA", comprising all the installations, apparatus, utensils, furniture and products in them, valued together at one hundred and sixty thousand pesetas". (Deed of Incorporation of the Laboratorios Grifols SA, November 18, 1940).

His wife, Magdalena Lucas, purchased 5 shares at a total value of 5,000 pesetas, which she undertook to pay in cash into the company's bank account on the day the company was incorporated. And Aureliano Mas also purchased 5 shares with a nominal total value of 5,000 pesetas which he also paid in cash into the social fund on the day of incorporation. The remaining 320 shares were left in the portfolio to be put into circulation when the General Assembly of Shareholders decided the time was right.

The minutes of the shareholders' meetings held at the Museu Grifols in Barcelona between 1940 and 1965 indicate the variations in the distribution of the shares created at the time of incorporation in 1940. The first extraordinary shareholders' meeting was held on June 30, 1941, and no longer included Aurelio Mas. The meeting stated that Grifols Roig had 172 shares in his own name, his wife Magdalena Lucas, 5 shares, and their three children (Maria Josefa, Victor and Josep Antoni Grifols Lucas) 1 share each. The remaining shares remained in the portfolio. Each share at this point had a nominal value of 1,000 pesetas each. It was founded as a family company. 
At a meeting on June 30, 1941, the shareholders put more shares into circulation, although all were bought by the family: the founder purchased 60 more shares, for a total sum of 60,000 pesetas, his wife 4 shares (4,000 pesetas) and each of the three children 2 shares $(6,000$ pesetas in total). In the minutes of a meeting on the May 23, 1942, it is stated that Grifols Roig was in possession of 230 capital shares and 100 founder shares, his wife 11 capital shares, his daughter and two sons 3 capital shares each. In total, the family unit controlled 250 capital shares and 100 founder shares, more than half of the 425 now in the share capital portfolio.

Outsiders entered the business, albeit in a very limited manner, shortly thereafter. On May 8, 1944, the minutes indicate that at the Ordinary General Shareholders' Meeting, José Segarra Bernils was present and held 5 capital shares. At the Ordinary General Shareholders' meeting of May 9, 1945, the name of Domingo Brasó Domingo, who held 100 capital shares, also appeared for the first time, and the minutes state that Segarra continued to hold 5 capital shares, the Grifols Roig children 3 capital shares each, the wife of the founder 9 capital shares and Grifols Roig 377 capital shares and 100 founder shares.

The reasons for incorporating outsiders into the company, particularly Domingo Brasó, are set out in the minutes of the shareholders' meetings of July 30, 1945 and April 15, 1946:

"[The President took the floor] to explain in detail to the shareholders' meeting the need for the company to increase its capital due to a number of circumstances, such as the general increase in the price of raw materials and all kinds of supplies and services, which makes it essential to have an ample cash flow to meet the needs of the company's business, and also to undertake the preparation of new products which have now been sufficiently studied and which it is therefore in the interest [of the company] to launch on the market as soon as possible". (minutes of July 30, 1945).

At the same meeting, it was agreed to increase the share capital from 500,000 pesetas to $1,000,000$ pesetas. To this end, 500 ordinary bearer shares with a par value of 1,000 pesetas 
each were created. Consequently, the capital of the company stood at 1 million pesetas, represented by one thousand bearer shares of 1,000 pesetas par value each, as ordinary shares. In addition, there were the 100 founder's shares "which do not represent capital or give the bearer the right to participate in the profits or assets of the company, but does give them the right to intervene in the system and administration of the company in the manner and to the extent determined by the bylaws". The founder shares were assigned to Grifols Roig, and could only be transferred to his wife and children, and were to be shared between them, expiring upon their death. In the event of an increase in share capital, it was agreed at this meeting that existing shareholders would have priority and preferential rights to sign up for new shares in proportion to the shares they already held (and the founding shares would count as ordinary shares for this purpose). In the deed of capital increase of May 9, 1946, the following persons appeared at the time of the increase and purchase of the new shares: Grifols Roig, his two sons, Domingo Brasó, and the widow Josefa Delapuerta Llupiá. Josefa Delapuerta purchased 119 shares, and in payment for them she signed over the urban estate of Sant Gervasi, which lay between the convent of Jesús María and Vendrell Street, to LG. This property, which was to be the new headquarters of LG, had three mortgages in the name of Juan Güell y Ferrer for three loans which he had made to Josefa Delapuerta and a loan called "censo". The property was transferred to LG in the 1946 deed of capital increase, and the company assumed the obligation to pay off the three mortgages and the debt that on the property. The brothers Josep Antoni and Victor Grifols Lucas each purchased 50 shares, contributing in payment of these "their detailed project for the installation of a penicillin factory, which belongs to them 50:50 pro-rata, and which is valued together at one hundred thousand pesetas". Grifols Roig bought 15 new shares for a total of 15,000 pesetas paying for them in kind with various objects, including a Leica Standard 
camera, a Summar lens, a Leitz enlarger, an optical desk for reading negative copies, a Letiz micro-photographic device which could be attached to the Leica, a large gas heater, a mediumsized autoclave, and a Mignon typewriter. Domingo Brasó subscribed the remaining 266 new shares for 266,000 pesetas, contributing this amount in cash that was deposited in the Company's cash office.

At the shareholders' meeting on June 10, 1955, the minutes list that the shareholders of all the registered shares of Ptas. 1,000 each, representing a capital stock of Ptas. 1,000,000, were:

Josep Antoni Grifols Roig; 395 shares

Domingo Brasó Domingo; 470 shares

Magdalena Lucas Viñas; 24 shares

Josep Antoni Grifols Lucas; 53 shares

Victor Grifols Lucas; 53 shares

Maria Josefa Grifols Lucas; 1 share

José Segarra Bernils; 2 shares

Thus, although the majority of the shares were in fact held by the Grifols family, the main individual shareholder was Brasó.

On the September 20,1958, at the General Meeting of Shareholders, the distribution of shares had hardly changed, although José Segarra had essentially withdrawn as a shareholder:

Josep Antoni Grifols Roig; 397 shares

Domingo Brasó Domingo; 470 shares

Magdalena Lucas Viñas; 24 shares

Josep Antoni Grifols Lucas; 53 shares 
Victor Grifols Lucas; 53 shares

Maria Josefa Grifols Lucas; 3 shares

Another interesting issue addressed at the meeting on September 20, 1958, was that the owners of the GRIFOLS brand (Grifols Roig and his two sons) leased the Grifols brand to LG for the benefit of all concerned, but in exchange they charged a royalty of $3 \%$ per year on sales, with a minimum payment of 300,000 pesetas per year (raised to 350,000 pesetas a few years later).

On May 30, 1959, at the shareholders' meeting, Josep Antoni Grifols Lucas was no longer a shareholder. Grifols Roig, as President, informed the shareholders at the meeting, after reporting that the automation of activities to reduce production costs was being studied in depth, that his son had died:

"I do not want to close these comments without dedicating a sincere remembrance to our late Dr. Josep Antoni Grifols Lucas, my son, who was the initiator of the activities of our Hemobanco and the Department of Plasma Fractions, which thanks to his work continue to follow their proposed course. In the hearts of all of us who worked and collaborated with him, we keep a deep memory for the intelligence, industriousness and chivalry that came together in him. RIP”. (minutes of May 30, 1959).

Josep Antoni's death meant that shortly afterwards (as of the July 10, 1962, meeting), Montserrat Gras Riera, his widow, joined the shareholders' group after inheriting his 53 shares.

More new shareholders, in relation to a capital increase, are recorded at the shareholders' meeting on May 30, 1960, when it is indicated that the automation process was continuing through loans made to the company by Domingo Brasó, Grifols Roig and son, Angel Devant and Antonio Ruiz, in anticipation of an approved capital increase which would involve Devant and Ruiz, who had appeared in alternate minutes for the previous 10 years as auditors, joining the company as minority shareholders. 
Secondly, with respect to the structure of corporate governance, the Grifols family showed an early and constant desire to organise the company professionally and to follow legal regulations. The corporate governance of these years combined a clearly personalist and hierarchical structure in the taking of long-term strategic decisions, centred on the President who was practically always the founder of LG, Grifols Roig, and had a very horizontal structure of middle management to which operational scientific, technical and administrative decisions were delegated. According to Grifols Roig, this coexistence of an owner with control over strategic decisions and managers in specialist areas within a very small company was in keeping with what was expected of a company which specialised in the pharmaceutical and biomedical profession, and whose reputation depended on that of its founder and scientific leader. In the minutes, Grifols Roig confesses that the decision to set up an independent company was met with criticism from the small world of Barcelona, where lies were spread that Grifols Roig, who had run the Institute of clinical analysis up until that point with other professional colleagues, would no longer take care of the analyses personally and would delegate professional activity to employees. At the Extraordinary General Meeting of July 2, 1941, it was stated that

"Dr. Grifols explained to those present that he had learned through various channels that elements interested in discrediting the activities of the company were disseminating the fact that the laboratory of analysis of Dr. Grifols had been incorporated into a public limited company and that consequently Dr. Grifols no longer dealt with it personally and that other employees were doing the work without direct interest, thus not deserving the trust he had previously enjoyed. As the damage which could be caused by the disclosure of this material could certainly be great, Grifols Roig proposes that the Board study what should be done to avoid this and, above all, to ensure that the heading of SA [the Spanish version of PLC] does not have to appear on any clinical analysis forms. [After deliberations, the Board unanimously agreed that] the clinical analysis laboratory which is the core of Dr. Grifols' professional activity should be separated from the company. To this end, Dr. Grifols will purchase the scientific equipment and furniture from the company for the same price as that for which they were provided, i.e. 15,675 pts for the 
scientific equipment and 3,995 pts for the furniture. And that the premises of the Office, Waiting Room, and offices continue to depend on the company, which will pay 550 pts for their rent instead of the 650 pts it had been paying". (minutes of July 2, 1941).

The fact that professional activity implied individual responsibility meant, as mentioned above, that the President of LG was almost always Grifols Roig during these years, except in the minutes of the May 12, 1942, when Aurelio Mas, the accountant who appeared in the deed of incorporation of LG was appointed President. As a very minor founding partner with only 5 of the 500 shares which made up the initial share capital, he was recorded as a shareholder in the minutes of the Ordinary Meeting of Shareholders held on November 19, 1940, and that of May 12, 1941, but then no longer appeared in the minutes as either a shareholder or President in subsequent years. The secretary of the shareholders' meetings, as recorded in the minutes of these years, was more variable. In the early 1940s both the wife and the daughter of the President and founder of LG appeared in this position, although as soon as the founder's sons joined the company, new shareholders began to replace the women in the family as secretary of the shareholders' meeting. The wife and daughter would, however, continue to appear as auditors at the shareholders' meetings, a position which Franco's legislation required and which had to be recorded in the minutes of company shareholders' meetings. The secretary at the first Ordinary General Meeting of shareholders on May 12, 1941 was Grifols Roig's wife Magdalena Lucas, who also filled this position at the first General Meeting of Shareholders on June 30, 1941, but at the Extraordinary Meeting on July 2 of that year the secretary was her daughter, Maria Josefa Grifols Lucas. After 1944 there were various shareholders with or without charge who were not members of the Grifols family: José Segarra who was recorded as secretary of the shareholders' meeting in the minutes of July 30, 1945, and Domingo Brasó, following the shareholders' meeting of April 15, 1946, and at the suggestion of Grifols Roig, was frequently 
the secretary of the Ordinary Shareholders' Meetings. At the shareholders' meeting on June 20, 1952, it was agreed that Brasó would be the President of the meeting and Jose Segarra the secretary, although on May 12, 1953, Grifols Roig was again President and Domingo Brasó secretary.

In the corporate governance of the company in the 1940s and 1950s, therefore, decision-making and the approval of balance sheets and accounts were shared between the various members of the close family of the founder, Grifols Roig, and the shareholders who came to own the company, particularly Domingo Brasó, who at times became, as has been indicated, the majority individual shareholder (1955) and even President of the shareholders' meeting (1952). Brasó, of whom hardly anything is known in existing publications about the history of Grifols in these years, was an industrialist in the beverage and ice sector who had a factory in a district of Barcelona called Sant Martí de Provençals, a factory where, according to oral testimony from the family, they rented space and regularly went in order to store plasma and other materials which needed to be refrigerated, as reliable refrigeration could not be guaranteed at the company's headquarters due to power cuts implemented by the Francoist autarchy (according to an interview conducted by Paloma Fernández with Victor Grifols Roura in Sant Cugat, February 13, 2015). Domingo Brasó is said to have been a friend of Grifols Roig, hailing from Molins de Rei, who, before the Civil War, already had ice factories with refrigerators and cabinets with ice inside, which were essential to the businesses of Grifols Roig who needed to freeze plasma. When Grifols Roig decided to set up the clinical analysis company as a public limited company, he involved Brasó as a partner. Brasó was therefore important because he contributed capital, and because he manufactured ice and rented the company his ice warehouses in the area of Avenida Marina in Barcelona, where the Mapfre Tower is located 
today, in front of Sal Costa. Grifols had a few refrigerators at the company headquarters in the 1940s, but they did not have the capacity they needed. Brasó had the ammonia technology necessary for making ice, since there was no gas supply available to produce it at the time, as well as the required safety permits, making him and his business premises essential to LG. Brasó's importance to LG was therefore twofold: as a capital partner who made it possible to double the company's share capital at a time when money was scarce in Barcelona at the height of the Franco regime, and because he had the facilities and capacity for refrigeration and freezing that LG needed for the perishable product in which Grifols had specialised since 1945, that is, plasma and its derivatives (Interview conducted by Paloma Fernández with Victor Grifols Roura in Sant Cugat on February 13, 2015).

Despite the fact that Brasó played a decisive role as a capital partner and as a collaborator by renting out his ice warehouses, Grifols Roig felt that the specialised work that he himself carried out and which gave LG their reputation clearly required recognition in terms of strategic decision-making, as well as in terms of salary, and he wanted this acknowledged in writing very explicitly from the moment the company was incorporated. For the patent and for the medical and professional work as manager, Grifols Roig was initially paid 2,000 pesetas per month, later increased to 3,500 ptas per month; for the commercial work, Grifols Roig was also paid the amount set out in the company's Articles of Association, 650 ptas, as rent for part of the property (from the minutes of the shareholders' meeting dated November 19,1940). With regard to the distribution of profits, at the Meeting held on April 15, 1946, it was agreed that Grifols Roig would receive $6 \%$ of the net profits as remuneration for his management role, $2 \%$ would be paid for services rendered to the Scientific Director, $2 \%$ for services rendered to the 
Technical Director, and the rest for the obligatory reserve fund, taxes, and for the purposes of the General shareholders' meeting.

In addition, the company's productive specialisation has undergone fundamental strategic diversification since the mid-1940s. In the organisation and definition of the functions of LG there was a before and after the creation of the Hemobanco. LG's corporate objectives, as set out in its Articles of Association, included the development of therapeutic and nutritional products and the performance of biomedical clinical analyses. The initiative of creating a Blood and Plasma Bank was, according to the minutes of the shareholders' meeting, driven by Josep Antoni Grifols Lucas, who along with his brother Victor, had learned from Duran i Jordà during the Civil War about the operation of the first blood bank established on the Aragon front. As students recruited to the front to help in health units, they learned how to store blood and were able to experiment with techniques which they later developed further and applied for civilian purposes when the war ended and they returned to the clinical analysis laboratory in 1940 . Grifols Roig had confidence in his sons, both good students (Josep Antoni studied Medicine and Pharmacy, and Victor studied Chemistry and Pharmacy), and both were lovers of reading and updating their medical and clinical knowledge and their competence in key languages (German, French and English for Josep Antoni and English for Victor, the languages in which scientific innovations in the area of medicine and clinical analysis were being published). Grifols Roig decided that, once again due to his reputation at LG, the new blood bank to be created with Grifols capital should operate independently and autonomously of the laboratory. In 1945 the Hemobanco was created, with Josep Antoni as its Scientific Director and Victor as its Technical Director. It was separated operationally from LG because of the importance at that 
time for LG of customers not thinking that Grifols Roig was going to stop dedicating time to LG because of calls made on him by the Hemobanco.

However, what is true is that the Hemobanco was gaining importance among the family businesses, not only because of increased sales, but also because of the need for investment to reduce costs. What began as an adventure by a young member of the Grifols family, in the shadow of LG, ended up being responsible for the highest volume of sales, and what would be the most important specialisation in the history of the Grifols group: plasma and its derivatives. The Hemobanco would end up being Grifols' main activity, and the Articles of Association and the corporate purpose of LG had to be modified to recognise this reality: blood and plasma activities brought more money in and had more future potential than clinical analysis and nutritional products or reagents. Barely five years after its inception, the Hemobanco had reoriented the entire activity of the company, its organisation, and its operation. In the minutes of LG's Ordinary Shareholders' Meeting of December 30, 1950, it is stated that

"due to the impetus given to the Blood and Plasma Bank, which is likely to increase, and by virtue of the fact that the plan for its organisation is practically complete, the current Scientific Director of the Company, who in fact carries the weight of the Bank's professional work, has much more purely medical work to do, and often overtime and urgent work, with more organisation and management work". (minutes of December 30, 1950).

The minutes point out that an increase in activity is to be expected, as well as an increase in the services provided by more doctors working with donors, and that in this case:

"The doctors who may be called in this case cannot and will not be considered as employees of this Company since they exercise a free profession, for which they pay a contribution and are registered, and therefore they will present their fee note to the company as appropriate. Accepting as indisputable that in the collection of human blood, for therapeutic cases, there is a phase, that of the recognition of the donor, which is a 
purely medical question, that the doctor performs with complete independence from the entire organisation of the Company, and for whose fees only the Medical Associations can dictate rules, it is natural that such a doctor should be paid as a professional and not be given an employee's salary. To this end, it is considered fair that the remuneration corresponding to the management of the auxiliary personnel of the donor service organisation should only be the statutory $2 \%$ of the profits, with the corresponding recognition of donors as professional fees. The complete management of these particular organisational services of the Blood and Plasma Bank requires that the doctor in charge of performing them usually has his own office in the company's premises. For this reason, the Company recommends that the physician subleases a room on the right-hand side of the entrance to the current office, where he can freely recognise the donors who need to be bled in his own office. Mr. Josep Antoni Grifols Roig said that it would be appropriate to propose that the management of the company be subordinated to the work of the board of directors, and to this end he proposed that it be partly entrusted to other people, so that they can devote more time to their professional work. Therefore, he offers to modify the monthly payment in the manner deemed appropriate by the Board, but charging $6 \%$ of the statutory benefits". (minutes of December 30, 1950).

For all these reasons, it was agreed to sublet the first room on the right-hand side of the Jesús y María laboratory to Josep Antoni Grifols Lucas, so that he could install his office there, paying 125 pts per month for the rental. Secondly, that Josep Antoni accepts the waiver of the monthly payment currently assigned to him and instead be paid the professional fee for medical examinations and scientific upon presentation of the corresponding notes and under the rules which may be established by the Medical Association as is customary in the City of Barcelona. It is clear from the minutes of the meeting on the May 23, 1951, that the Hemobanco gradually took on more activity, including that of LG, in which the manager stated that the owner of a pharmaceutical laboratory which prepared products with penicillin had been talking to him, and the manager had suggested that he might like to manufacture his own penicillin, even on a small scale, and in this context the manager offered to sell him the project and health permit they had for manufacturing penicillin. However, the minutes continue to explain, since the government 
had just granted manufacturing exclusivity to two large pharmaceutical institutions, "the hope of being able to sell penicillin manufactured in a relatively modest facility is completely illusory, and that besides being our main activities dedicated to the Blood and Plasma Bank we lack space and time to dedicate to the manufacture of Penicillin. Therefore, the Manager advises careful deliberation of the convenience of buying the mentioned project and Health permit".

On June 16, 1958, the tendency of the Hemobanco to be the main source of income for the family business, and that it should therefore be invested in, is made explicit:

"It must be considered that the highest percentage of sales is recorded by our Hemobanco Department, which is still in an experimental or evolutionary period. Its services are required more and more by the medical class in general, but in spite of this, its maintenance still costs money. The price of the Hemobanco's services is very low in relation to its cost and due to the nature of these services it is not prudent to increase it. In order to reduce this cost, which is when this a department will no longer be a burden, suitable apparatus is needed that cannot be obtained in Spain, appropriate installation, etc. ..., all of which means that the proper method is not used, making it expensive. Apart from this, research work on haematology is constantly being carried out in this section, in which assets and raw materials are invested in quantity, aimed at obtaining, as in other advanced countries, by-products of human blood of high therapeutic value. Recently we have made available to the medical class in general active human fibrinogen and human albumin, both truly life-saving products in certain cases, but commercially they have proved to be a failure for the moment, given their high manufacturing cost and the fact that a large part of the medical class is still unaware of their existence. This means, and we have no doubt that [shareholders] will take this into account, that in our case the volume of sales is not a sign that can be used as a basis for calculating profits. (...) We have applied for, and we believe will be granted, permission to import foreign equipment and, in addition, the work being done on preparing new human blood by-products offers the best prospects. (...)

"All this leads me to express my sincerest conviction of the need for a capital increase so that we can carry out the necessary publicity campaign for the sale of the new products I have mentioned to you, the necessary modification work to properly organise the production and storage, and the importation of the apparatus we have requested and for 
which we have found the Ministry of Commerce to be positively inclined towards, which warrants being taken advantage of'. (minutes of June 16, 1958).

At the shareholders' meeting held on November 25, 1964, it was resolved to amend the Company's Articles of Association to specify that one of the central objectives of LG would be to provide services to the Hemobanco, which since 1945 had been excluded from the company's objectives to protect the reputation of Grifols Roig and LG in its initial corporate objectives, which were more closely linked to the production of therapeutic and dietetic reagents and products:

"The Presidency, after listing the difficulties encountered since the Society's foundation, concerning the social objectives that were initially expressed in the practice of clinical and biological research and the preparation of therapeutic and dietetic reagents and products and subsequently since 1945, given the particularity of having specialised with evident success in the clinical and biological analytical techniques proper to blood banks and their derivatives [stated that] the central purpose of the Company is to continue and increase, to the extent possible, these services of the Blood and Plasma Banks, as one of its unique social objectives, which is why an express financial program will be carried out, proposing in view of the aforementioned the convenience of specifically including the aforementioned services within the corporate purpose. The Meeting unanimously approved the proposal and amended Article 3 of the Bylaws, which read as follows: Art.3. The object of this Company shall consist of the practice of clinical and biological research and the preparation of therapeutic and dietetic reagents and products and, in particular, the services of blood bank and plasma derivatives, in the analytical-clinical and biological techniques inherent to them". (minutes of November 25, 1964).

On December 5, 1964, the shareholders' meeting agreed to increase the company's share capital by 17 million pesetas, to 18 million, in order to buy land and make investments that would eventually lead to the creation of the new blood and plasma derivatives factory in Parets del Vallés. What started out in 1945 almost as an addition to the family business in order to give the young son of the owner of a prestigious laboratory an avenue for growth ended up being the core business of a large business group. 
LG, therefore, between 1940 and 1965, had two major stages from the point of view of specialisation: between 1940 and 1945, when the small family pharmaceutical products business began to become more organised; and then from 1945, when the business diversified into a very knowledge- and capital-intensive activity which required the share capital to be increased, incorporating shareholders from outside the family, and changing the management organisation of the new specialities and units of the business by taking advantage of the capacity and competence of young family members as well as trained employees from Barcelona's medical health district and German laboratories, due to the effects of the World War II and the persecution of Jewish scientists known to the family since Grifols Roig's stay in Germany in 1909 (Fernández-Perez 2019).

The commitment to develop new biomedical, pharmaceutical and clinical specialities meant constant investments, the reinvestment of profits in the company's reserve fund, capital increases for close trusted partners, and slow progress in the distribution of dividends over these years. The minutes of the shareholders' meetings are a testimony to the constancy of the reinvestment of profits, and the renouncing of dividend distributions in these key years of investment and the creation of the new knowledge- and capital-intensive businesses. The years with the lowest profits are also years of heavy investment, such as 1940 when the laboratory was set up and machinery and furniture were purchased, and 1946 when the new Hemobanco was launched. In 1958, however, negative profits were, according to Grifols Roig's testimony in the minutes of the shareholders' meeting of that year, due to the lack of a method for reducing costs and increasing productivity, and to an organisational problem which would become more acute after the death of Josep Antoni Grifols Lucas, and which would be tackled resolutely from 1960 onwards through what would be an alliance with an American partner (Dade Reagents - 


\section{Journal of Evolutionary Studies in Business}

and the creation of Dade Grifols - and American Hospital Supply Corp. (AHS), following the death of the founder of Dade Reagents and the company's sale by his widow to AHS) that would give a boost to the company's organisational and technological renewal.

FigURE 1. Benefits of Laboratorios Grifols 1940-1964 (pesetas at the time)

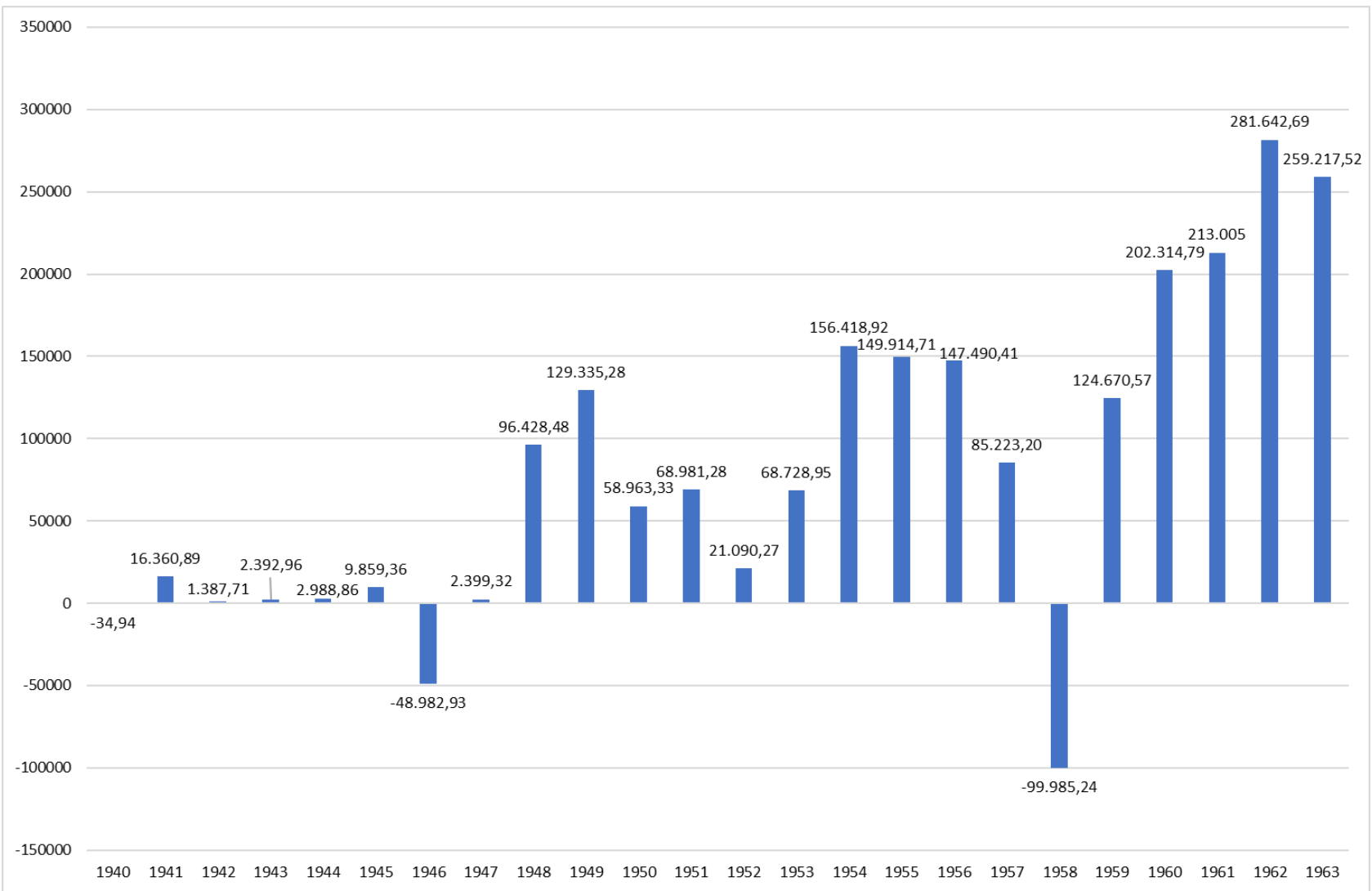

Source: Grifols Historical Archive in Barcelona. Minutes of the shareholders' meeting of Laboratorios Grifols S.A. 1940-1964 And Deed of Incorporation of Laboratorios Grifols SA.

\section{Conclusions}

The work we present here is an example of how small dynastic family firms in science industries that endure over time not only acquire specialised knowledge to compete in the market, but also knowledge about transferring and absorbing new knowledge from younger generations to ensure the continuation of the family business. Without the idea of opening a Blood Bank under the personal direction of Josep Antoni Grifols Lucas in the mid-1940s, maybe Laboratorios 
Grifols SA would have never grown anywhere near as much if they had simply stuck with the original activity of the founder (clinical analysis, nutritional products or their attempt to produce penicillin). The outward looking, professional and tolerant communication and coordination between members of the different generations of the Grifols family, and their close colleagues in the city of Barcelona and abroad, allowed for the early embeddedness of innovation in the strategic decision making of the laboratory. All the partners involved in the ownership and management of the firm established continuous small changes which left room for new ideas and new products, regardless the age or the experience of the person in the firm proposing the ideas. Grifols Roig gave enormous freedom to his sons, and placed his trust in their scientific initiatives, and the sons accepted their father's controlling top-down managerial decisions. Interdisciplinary historical analysis has helped us see how a small private clinic in Barcelona in the late 19th century used very modern coordination and professional attitudes that allowed for continuous innovation in its practices, both in science and in business. As some authors have indicated, the early imprinting of practices of innovation in family businesses in healthcare activities may help understand their distinctive growth and internationalisation (Donzé and Fernández-Perez 2019 and Garcia-Ruiz and Fernández-Perez 2017).

On the one hand, we have been able to understand how the Grifols family adjusted its different medical practices to a changing scientific paradigm, which was crucial to the survival of the family's business at the end of the 19th century. This adaptation left behind ways of understanding medicine which persisted during the subsequent years of activity, and which are still latent in the company's organisation today. The four business divisions which currently make up the Grifols holding company are a result of the different medical practices in which the family specialised during the 20th century, i.e. diagnostic and therapeutic practices (both 
haemotherapy and nutrition): Bioscience is the division in charge of the production of plasmaderived medicines; Diagnostic is the division in charge of developing diagnostic solutions in transfusion medicine; Hospital is in charge of meeting the needs of hospital pharmacies, such as the use of intravenous solutions or special formulations for clinical nutrition; and finally, Bio Supplies provides the different biological materials needed for health science research. This adaptation, both in scientific practices and in epistemology itself, was accompanied by a significant technological innovation of its own and a strong local and international network of contacts, which managed to build up its own clientele (both among the medical class and among individuals) in order to survive in precarious national markets.

On the other hand, thanks to an analysis of the minutes of Grifols Laboratories shareholders' meeting, we have been able to understand why the company was incorporated after the war and then diversified its scientific activity. Both strategies, scientific modernisation and business modernisation, are equally necessary to explain the current company's success.

\section{Acknowledgements}

Cristina Sans-Ponseti acknowledges support from the Research Project PID2019-105131GBI00 (Ministerio de Ciencia, Innovación y Universidades) and the Industrial Partnership Project DI 201773 between Universitat Autònoma de Barcelona and Grifols SA (Generalitat de Catalunya).

Paloma Fernández has received financial support from the Research Project PGC2018-093971B-I00, funding from: Ministerio de Ciencia, Innovación y Universidades (MCIU), Agencia Estatal de Investigación (AEI) and the European Regional Development Fund (ERDF). She has also benefitted from a non-profit agreement (signed in 2014) with the Grifols Group to conduct 
research into the Grifols historical archive, within which constant support and guidance has been received from Nuria Pascual and Rosa Avella. Particular appreciation is expressed also to Victor Grifols Roura for the interview with Paloma Fernández in the Grifols office in Sant Cugat del Vallès on 13th February 2015.

\section{Archives}

\section{Grífols Historical Archive}

Celis, Lluís, Josep Antoni Grifols Roig, and Ricard Moragas. ca. 1915. Laboratorio de Investigaciones Biológicas. Barcelona: Instituto Central de Análisis Clínicos, Bacteriológicos y Químicos (Reference Grifols Historical Archive: MG0453).

Grifols Roig, Josep A. 1928a. Flebula aspiradora Grifols: aparato para extraer automáticamente sangre y otros fluidos del organismo humano y animal destinados al anàlisis. Barcelona: Departamento de Biología de la Sociedad General de Farmacia, SA (References Grifols historical Archive: MG0761, MG6495 and MG2054).

Grifols Roig, Josep A. 1933c. La vacunoterapia por ingesta en las afecciones colibacilares. Barcelona: Departamento de Biología de la Sociedad General de Farmacia, S. (Reference Grifols historical Archive: MG0427).

Laboratorios Grifols. 1944. Equipo para la determinación de los grupos sanguíneos. Barcelona: Hemobanco de Sangre y Plasma de Laboratorios Grifols, SA.

Laboratorios Grifols. 1951. El Banco de Sangre y Plasma de Laboratorios Grifols. Barcelona: Hemobanco de Sangre y Plasma de Laboratorios Grifols, SA.

Laboratorios Grifols. 1953. Memoria del Hemobanco. Barcelona: Laboratorios Grifols, S.A. (Reference Grifols historical Archive: MG6353).

Shareholders Meeting Minutes, from November 1940 to December 1964, Shareholders Meeting records, Grifols Historical Archive, Barcelona.

Oficina Española de Patentes y Marcas

Grifols Roig, Josep A. 1916. Un aparato perfeccionado para la obtención de muestras de sangre, destinadas al anàlisis. Invention patent number 62983. Madrid: Oficina Española de Patentes.

Grifols Roig, Josep A. 1917. Resultados posibles en la fuerza de la reacción, según nuestro método. 
Trademark number 31936. Madrid, Espanya: Oficina Española de Patentes.

Grifols Roig, Josep A. 1929a. Ampollas previamente preparadas autoaspiradoras y autoinyectables. Invention patent number 111456. Madrid: Oficina Española de Patentes.

\section{Reichspatentamt Patentschrift}

Grifols Roig, Josep A. 1928b. Bluttransfusionsapparat. Invention patent number 569.648. Berlin: Reichspatentamt Patentschrift.

Brevet d'invention Délivré Sans Garantie du Gouvernement

Grifols Roig, Josep A. 1929b. Dispositif pour injections ou prélevements de sang. Invention patent number 671969. Paris: Brevet d'invention Délivré Sans Garantie du Gouvernement.

Patent Specification of his Majesty's Stationery Office

Grifols Roig, Josep A. 1929c. Needle Holder for Ampules. Invention patent number 308.597. London: Patent Specification of his Majesty's Stationery Office.

\section{United States Patent Office}

Grifols Roig, Josep A. 1933b. Blood transfusion apparatus. Invention patent number 1923846. Washington: United States Patent Office.

\section{Hospital de la Santa Creu i Sant Pau Archive}

Hospital de la Santa Creu i Sant Pau. 1948. Libros mayores. Barcelona: Hospital de la Santa Creu i Sant Pau.

Arxiu Històric de Protocols Barcelona - Il-lustre Col-legi de Notaris de Catalunya

Faura Bordas, José. 1940. Protocolo número 1798. Barcelona: Archivo de Protocolos de Barcelona.

\section{Interviews}

Grifols Roura, Victor, interview by Paloma Fernández-Pérez, February 13, 2015, Sant Cugat. 


\section{References}

Avellà, Rosa and Miquel, Berta, eds. 2015. Cuando un sueño se cumple. Crónica ilustrada de 75 años de Grifols. Barcelona: Grupo Grifols, SA.

Brunton, Deborah, ed. 2004. Medicine Transformed: Health, Disease and Society in Europe, 1800-1930. Manchester: Manchester University Press.

Cunningham, Andrew, and Perry Williams, eds. 1992. The Laboratory Revolution in Medicine. Cambridge: Cambridge University Press

Donzé, Pierre-Yves, and Paloma Fernández-Pérez. 2019. "Health Industries in the Twentieth Century." Business History 61(3): 385-403. doi: 10.1080/00076791.2019.1572116.

Fernández-Pérez, Paloma, and Ferran Sabaté. 2017. "Entrepreneurship and management in the therapeutic revolution: The modernisation of laboratories and hospitals in Barcelona, 1880-1960." Investigaciones de Historia Económica 15(2): 91-101. doi: 10.1016/j.ihe.2017.09.001.

Fernández-Perez, Paloma, Núria Puig, Esteban García-Canal, and Mauro F. Guillén. 2019. "Learning from giants: Early exposure to advance Markets in the growth and internationalisation of Spanish Health care corporations in the twentieth century." Business History, 61(3): 404-428. doi: $\underline{10.1080 / 00076791.2017 .1369528 .}$.

Fernández-Pérez, Paloma. 2019. "Pioneers and Challengers in the Global Plasma Protein Industry, 1915-2015." Historical Social Research, 44(4): 75-95. doi: 10.12759/hsr.44.2019.4.75-95.

García-Canal, Esteban, Mauro F. Guillén, Paloma Fernández-Perez, and Nuria Puig. 2018.“Imprinting and early exposure to developed International Markets: The case of the new multinationals." Business Research Quaterly 21:141-152. doi: 10.1016/j.brq.2018.05.001.

Garcia-Ruiz, José Luis, and Paloma Fernández-Pérez. 2017. "Financing the Internationalization of Spanish Industrial SMEs, 1980-2000. The Case of the Grifols Group." Universia Business Review, 55: 64- 80.

Grifols Group. 2000. Notes of Victor Grifols Lucas. Barcelona: Grupo Grifols, SA.

Grifols Group. 2001. Dedicado a la vida: Grifols, 60 aniversario. Barcelona: Grupo Grifols, SA.

Grifols Lucas, Victor. 1945. Proyecto penicilina. Manuscript of Laboratorios Grifols, SA.

Grifols Lucas, Victor. 2009. Amb un suro i un cordill. Vivències d'un empresari de postguerra. Barcelona: Grifols Group, SA.

Grifols Morera, Josep A. 1904. "Modo y razón de ser de la homeopatía." Revista Homeopática Catalana $3(2): 30-42$

Grifols Roig, Josep A. 1913. "Contribución al perfeccionamiento del método y técnica de la Reacción de Wassermann.” PhD diss., Universitat de Barcelona. 
Grifols Roig, Josep A., and Kurt Helmholz. 1924. "Einfache minimetrische Methode zur Bestimmung des Harnstoffs im Blut, in der Spinalflüssigkeit und im Urin mit Hilfe von Permutit.” Deutsche Medizinische Wochenschrift, 51(4): 146-147.

Grifols Roig, Josep A. 1933a. "La transfusió de sang citratada per mitjà de la flèbula transfusora." Annals de l'Hospital Comarcal de Vilafranca del Penedès 1: 49-65.

Ludwig-Maximilians-Universität München. 1909. Personalstand der Universität. Winter-Semester 1909/10. München: Universitäts-Buchdruckerei Dr. C. Wofl \& Sohn.

Mateo de la Hoz, Mónica. 2015. "Historia del Instituto Llorente (1894-1997).” PhD diss., Universidad Complutense de Madrid.

Moragas, Ricard, and Grifols Roig, Josep A. 1914. "Presentació d'un nou aparell per hemocultius aerobis y anaerobis." Anals de l'Acadèmia y Laboratori de Ciències Mèdiques de Catalunya 9: 423-427.

Moragas, Manuel. 1915. "Normas de conducta del médico homeópata ante los modernos descubrimientos biológicos." Revista de Homeopatía Práctica, 4: 89-100.

Moragas, Ricard, and Josep A. Grifols Roig. 1916. "Presentació d'un tub de fermentació per a cultius, aplicable a la investigació del coli en les aigües." Anals de l'Acadèmia y Laboratori de Ciències Mèdiques de Catalunya 10: 77-79.

Morell, Joan. 1996a. "Historia e historias de la industria farmacéutica barcelonesa (primera parte)." Butlletí de la Societat d'Amics de la Història i de la Ciència Farmacèutica Catalana 5(11): 4245.

Morell, Joan. 1996b. "Historia e historias de la industria farmacéutica barcelonesa (tercera parte)." Butlletí de la Societat d'Amics de la Història i de la Ciència Farmacèutica Catalana 5(13): 2531.

Palfreeman, Linda. 2016. Spain Bleeds. The development of battlefield blood transfusion during the Civil War. Brighton: Sussex Academic Press.

Piqué, Joel. 2018. "Procesos de construcción social y científica de la homeopatía en Cataluña (18901924)." PhD diss., Universitat Autònoma de Barcelona.

Piqué, Joel. 2019. "El 'específico homeopático': legitimación comercial de la homeopatía en Barcelona (1902-1910)." História, Ciência, Saúde-Manguinhos 26(4): 1337-1354. doi: 10.1590/s0104$\underline{59702019000400018 .}$.

Puig Rovira, Francesc X. 2003. Diccionari biogràfic de Vilanova i la Geltrú. Ajuntament de Vilanova i la Geltrú.

Schneider, William H. 2003. "Blood transfusion between the wars." Journal of the History of Medicine and Allied Sciences 58(2): 187-224. doi: 10.1093/jhmas/58.2.187. 


\section{Journal of Evolutionary Studies in Business}

Starr, Douglas. 1998. Blood: An Epic History of Medicine and Commerce. New York: Alfred A. Knopf, Inc.

Tatjer, Mercedes. 2006. "La industria en Barcelona (1832-1992). Factores de localización y cambio en las áreas fabriles: del centro histórico a la región metropolitana." Scripta Nova. Revista electrónica de geografía y ciencias sociales 10(218): 46.

Zarzoso, Alfons and Martínez-Vidal, Àlvar. 2016. "Laboratory medicine and surgical enterprise in the medical landscape of the Eixample district." In Barcelona: An Urban History of Science and Modernity, 1888-1929, edited by Oliver Hochadel and Agustí Nieto-Galan, 69-72. London: Routledge.

Zarzoso, Alfons. 2018. "Medicina i cirurgia en temps de guerra". In Història mundial de Catalunya, edited by Borja De Riquer, 762-769. Barcelona: Edicions 62.

Zarzoso, Alfons. 2020. "Lluis Celis i Pujol.” Galeria de Metges Catalans, Accessed August 2020. http://www.galeriametges.cat/galeria-fitxa.php?icod=EMG. 